\title{
Basilar Invagination or Impression: Steeping at the Angle of Craniovertebral Junction
}

\section{Baziler İnvaginasyon/İmpresyon: Kraniyovertebral Kavşak Açısının Dikleşmesi}

Keywords: Craniovertebral junction, basilar invagination, basilar impression, ALS

Anahtar Kelimeler: Kraniyovertebral kavşak, baziler invaginasyon, baziler impresyon, ALS

\section{Dear Editor,}

A 40-year-old male patient with walking difficulties was referred to our clinic with a preliminary diagnosis of amyotrophic lateral sclerosis (ALS). Abnormalities in the skull base and craniovertebral junction (CVJ) play a crucial role in the differential diagnosis of ALS (1). The CVJ consists of condyles of the occipital bone, atlas, and axis of the spine and their joints (2). CVJ abnormalities may be hereditary, developmental or present due to malformation secondary to any acquired disease process (3). Any course that could lead to a defect of these structures can lead to CVJ abnormalities.

A congenital or acquired abnormality in the odontoid process, which is above the foramen magnum, is called invagination or impression (Figure 1,2). Basilar invagination and impression are often incorrectly used synonymously; however, they refer to different meanings and should not be used interchangeably. Basilar invagination is congenital and is a condition in which vertebrae components are displaced upwards from the foramen magnum in normal bone. By contrast, the same action of the dens due to a defect of bones in the skull base is defined as a basilar impression
(4). Stenosis of the foramen magnum may lead to compression of the bulbus and cause neurologic symptoms similar to those of ALS (5).

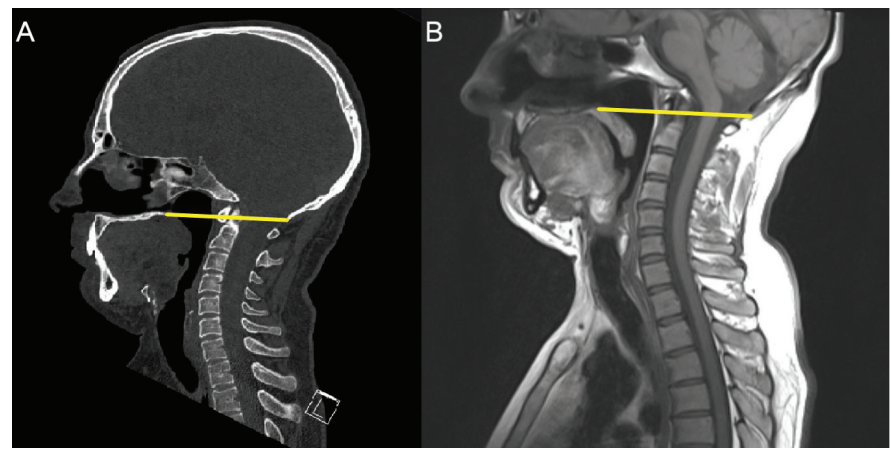

Figure 1. Patient's (A) cranio-cervical CT and (B) cranio-cervical MRI $\mathrm{T} 1$ weighted sagittal section. It can easily be seen that the top of $\mathrm{C} 1$ is about $0.6 \mathrm{~cm}$ above Chamberlain's line (yellow line)

CT: Computed tomography, MRI: Magnetic resonance imaging

Address for Correspondence/Yazışma Adresi: Mehmet Güney Şenol MD, University of Health Sciences Turkey, Istanbul Sultan 2. Abdulhamid Han Training and Research Hospital, Clinic of Neurology, Istanbul, Turkey Phone: +90 2165422020 - 3803 E-mail: mgsenol@yahoo.com ORCID: orcid.org/0000-0001-6397-9293 Received/Geliş Tarihi: 25.01.2020 Accepted/Kabul Tarihi: 07.01.2021 

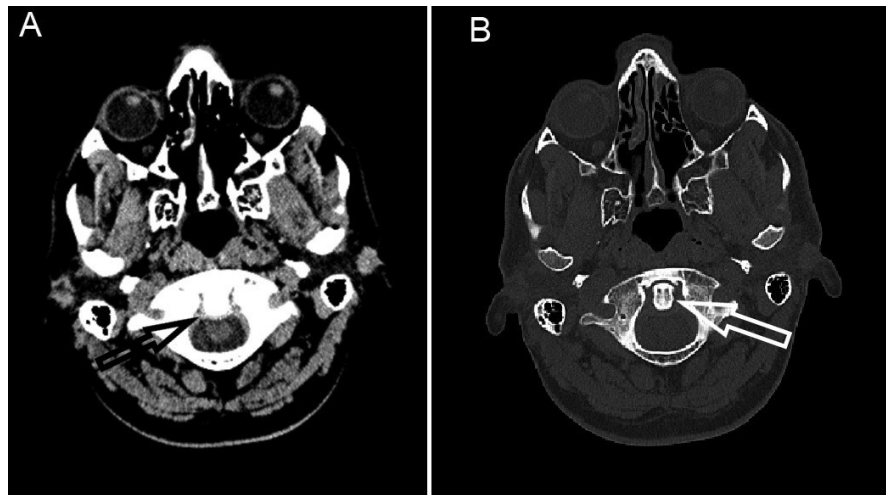

Figure 2. Cranial computed tomography images show (A) reduction of the anterior subarachnoid space with no compression of the medulla spinalis (black arrow) and (B) dens protrusion into the infratentorial region with compression (white arrow)

\section{Ethics}

Informed Consent: Written informed consent was obtained.

Peer-review: Externally peer-reviewed.

\section{Authorship Contributions}

Surgical and Medical Practices: M.G.Ş., Ş.I., Concept: Ş.I., Design: M.G.Ş., Data Collection or Processing: Ş.I., Analysis or Interpretation: M.G.Ş., Literature Search: M.G.Ş., Ş.I., Writing: M.G.Ş.

\section{References}

1. Bromberg M. Differential Diagnosis of MND. In: Bromberg M, (ed). Motor Neuron Disease in Adults (Contemporary Neurology Series). New York: Oxford University Press; 2014:102-108.

2. Schweitzer ME, Hodler J, Cervilla V, Resnick D. Craniovertebral junction: normal anatomy with MR correlation. AJR Am J Roentgenol 1992;158:1087-1090.

3. Chen YF, Liu HM. Imaging of craniovertebral junction. Neuroimaging Clin N Am 2009;19:483-510

4. Shah A, Serchi E. Management of basilar invagination: A historical perspective. J Craniovertebr Junction Spine 2016;7:96-100.

5. Sawaya, RA. Foramen magnum meningioma presenting as amyotrophic lateral sclerosis. Neurosurg Rev 1998;21:277-280. 